\title{
IMPACT OF COMPANY INCOME TAX ON CORPORATE PROFITABILITY IN NIGERIA
}

\author{
Dr. Akadakpo Bukola Adefunke \\ Senior Lecturer \\ Department of Accounting \\ Faculty of Management Sciences \\ University of Benin, Benin City, Edo State, Nigeria \\ E-mail: adefunke.akadakpo@uniben.edu \\ Dr. Akogo Obehioye Usiomon \\ Lecturer \\ Department of Accounting \\ Faculty of Management Sciences \\ University of Benin, Benin City, Edo State, Nigeria \\ E-mail: ehioshioobehioye@gmail.com
}

Received: October 27, $2021 \quad$ Accepted: December 30, $2021 \quad$ Online Published: January 25, 2022

DOI: $10.46281 / \mathrm{ijfb.v9i1.1567}$

URL: https://doi.org/10.46281/ijfb.v9i1.1567

\begin{abstract}
The study examined the impact of company income tax on corporate performance. The study used data from twelve (12) listed firms on the Nigerian Stock Exchange, of which data for the study was collected from the annual reports of the companies, and regression analysis was used as a technique for data analysis using SPSS 2020. The data span across ten (10) years from the period of 2011-2020. Findings from the study revealed that Company income tax (CIT) has a positive and significant effect on profit after tax (PAT) and returns on equity (ROE). Change in shareholders' funds (CSHF) has a negative yet significant effect on ROE, while CIT has a significant and positive effect on shareholders' earnings. Following the results from the research analysis, the study recommended that the fiscal policy adopted in Nigeria should consider the circumstances surrounding the activities of companies located in the Country and the special role they play in the pursuit of the economic growth of the nation. Tax incentives and positive tax reforms that could reduce the burden and liability of tax on companies in Nigeria should be incorporated in the fiscal policy to encourage their business activities and going concerns.
\end{abstract}

Keywords: Company Income Tax (CIT), Profit after Tax (PAT), Returns on Equity (ROE), Change in Shareholders' Funds (CSHF).

JEL Classification Codes: H25, O16.

\section{INTRODUCTION}

The Company Income Tax (CIT) was created by the Companies Income Tax Act (CITA) which was enacted in the year 1979 which originates from the Income Tax Management Act of 1961. The federal government of Nigeria implemented its Voluntary Assets and Income Declaration Scheme (VAIDS) which kicked off from July 2017 down to June 2018, purpose of which was to present defaulting 
taxpayers an opportunity to regularize their tax affairs with full amnesty (KPMG Nigeria, 2019). According to KPMG Nigeria (2019) "the approach was modestly successful since it assisted the FIRS in its ability to expand the tax net and achieve its record tax revenue collection of $\$ 5.3$ trillion in 2018". In 2019 the actual tax revenue generated was $\$ 5,263.1013$ trillion of which Company Income Tax was 1607.3201 trillion which is about 31\% of total tax revenue for 2019 (Federal Inland Revenue Service, 2020).

To further explicate, there are three tax authorities in Nigeria charged with the ability to collect various designated taxes, the Federal Inland Revenue Service (FIRS) which is the operating arm of Federal Inland Revenue Service Board, is responsible for collecting taxes on behalf of Federal government, example of which include (Company Income Tax, Withholding Tax, Petroleum Profit Tax, Value added Tax etc.), the State Inland Revenue Services (SIRS) collecting State taxes, some examples of which include (Personal Income Tax, PAYE, individuals withholding tax, road tax etc.) and the Local Government Revenue Committee (LGRC) which collect taxes like Shop and Kiosk rates, Tenement rates, On and off liquor license etc. (Institute of Chartered Accountants of Nigeria, 2019).

Corporate organizations all over the world are required to pay what is known as company income tax. Company income tax is a mandatory payment imposed for various years of assessment on the profit of companies deemed to have been accrued, derived or brought into a country. For taxation purpose, companies are broadly classified into Nigerian companies (which are companies incorporated under the Companies and Allied Matters Act (CAMA) 2020 as amended, and any profits made by such companies may be deemed to have accrued, derived or brought into Nigeria) and foreign companies (which are companies established under laws not enforceable in Nigeria, and any profit made by such company may be deemed to have accrued, been derived from or arisen from outside Nigeria, to the extent that they are not attributable to activities within Nigeria).

The importance of tax as a major form of revenue to Nigerian government expenditure cannot be overemphasized. Although the Nigerian economy is centered on oil revenue, taxes over the years have contributed significantly to the Gross Domestic Product (GDP) of the country. One of the major problems with Nigeria's tax system is the way and method of tax administration and the failure of the government to effectively utilize such funds.

Nigeria today is facing series of challenges when it comes to optimizing tax revenue for economic and social growth. The role of tax revenue with regards to promoting economic activities and growth is not felt in Nigeria because despite tax revenue and expenditure reported year in year out by government, the physical conditions of the nation in terms of social amenities and infrastructure is dwindling and gradually moving to a pit of no return. This can evidently be seen in the lack of basic social amenities.

Another problem being faced in the country is finding the optimal balance between a tax regime that is business and investment friendly while at that same period generating enough revenue to cover public expenditures which in turn attracts potential investors. Corporate organizations are faced with the issue of being subjected to tax on the profits made by its holding company and that of its foreign subsidiaries and branches. Some firms indulge in tax evasion and avoidance practices, all in a bid to avoid the issue of double taxation and some other challenges posed by corporate taxes. In other to curb these challenges, a balance between government goals and objective in terms of revenue generation through tax and the goals of corporate organization should be reached so as to ensure sustainable growth and development (Agbetunde, 2010). Corporate organizations loose huge amount of profit in form of tax year in year out, where such loss of profit is ploughed back into the company and effectively utilized, it can change the fortunes of the company and that of its stakeholders. The importance of corporate profitability and of keeping a low corporate tax rate cannot be overemphasized. It is such that every government that considers economic and employment growth a priority must reflect in their fiscal policy (Cordelia \& Amah, 2018).

There is an urgent need to examine deeply the relationship between various corporate taxes (Petroleum Profit Tax (PPT), Company Income Tax (CIT) and Personal Income Tax (PIT)) on the performance firms in Nigeria. The corporate taxed examined for the purpose of this study is the Company Income Tax. 


\section{Conceptual Framework}

Tax charged by government is based on the profit of the organization, and the Profitability depends on the ability of a firm to produce more revenue which is capable of absorbing all expenses incurred in generating such revenue, including tax and still have a balance called retained earnings which could be absorbed back into the business for expansion (Omodero \& Amah , 2018).

Corporate taxes are one of the major sources of revenue available to finance government expenditures and it's also an important factor that determines capital investment in every nation of the world (Ileana, Aurelia, Minzu, Popa, \& Niculescu, 2016). Companies Income Tax (CIT) is a tax imposed on the profits of registered companies in Nigeria and those of foreign companies carrying on any business in Nigeria. Companies Income Tax Act, 2007 (as amended) is a principal law that regulates the taxation of companies in Nigeria and also empowers the Federal Inland Revenue Service Board (FIRSB) with the ability to assess and collect taxes from all limited liability companies that carries out their operation from or within Nigeria except those specifically exempted from tax by the ACT. Tax system is structured in a way that allows domestic corporations to be taxed on its assessable profit which is generated from all its activities carried out globally while foreign corporations are subjected to tax only on income from domestic activities within the jurisdiction (Adejare, 2015). After all allowable expenses have been deducted of as specified by the Act; companies are required by the Act to pay $30 \%$ of their assessable profit to the government as tax. However, the CIT rate for small companies is $0 \%$ for companies with gross turnover of $\$ 25$ million or less and that of medium companies with gross turnover greater than $\$ 25$ million and less than $\$ 100$ million to be $20 \%$ (Pricewaterhousecoopers, 2021).

Organizations are also subjected to various taxes such as property tax, withholding tax, customs duties, payroll tax, and excise tax, value added tax and other taxes which however, are rarely referred to as "corporate tax." (Adejare, 2015). The Federal Inland Revenue Service (FIRS) is the body charged primarily with the responsibility to administer tax on behalf of the government (Omodero \& Amah , 2018)

\section{Corporate Performance}

Corporate performance is a compound evaluation of how well a firm effectively and efficiently carries on its vital functions which are typically the market, financial and shareholder performance. The Corporate performance of a firm deals with the "health" of an organization, which over time has been traditionally evaluated in terms of financial performance (Wigmore, 2015).

Corporate performance entails the actual output of a firm as measured against its projected results (or goals and objectives) which aims to reflect the effectiveness and efficiency to which management have utilized its resources. A high performance rating of an organization eschews disagreement between the management and the shareholders. Many measures over time have been adopted in evaluating corporate performance. Ra'Ed, Idries, and Mohammad (2015) suggested that performance could be evaluated either subjectively or objectively. The objective measurement in general relies on financial data which are usually of its historical nature, while the subjective evaluation is determined by managerial assessments.

Various performance indicators have been employed by researchers and other users of the financial statement in its studies, some of which includes the use of statistical techniques such as multiple regression and discriminant analysis. Others consist of single variables that are based on absolute values, percentage or ratios, example of which can be found on accounting-based measures, i.e., figures and ratios that are gotten from the financial statements such as return-on-assets (ROA), return-on-equity (ROE), return on capital employed (ROCE) etc. (Kurawa \& Saidu, 2018). For the purpose of this study, corporate performance is restricted to the return-on-assets (ROE), Earnings per share (EPS), Profit after tax (PAT).

\section{Theoretical Framework}

Two major theories adopted by this study are the benefit theory and the ability to pay theory. 


\section{The Benefit Theory}

The benefit theory assumes that tax payers pay for the proportionate amount of government benefit they receive. That is, it is founded on the assumption of an exchange relationship that exists between taxpayers and the state government and that the taxpayers with the largest benefit from benefits made available by the government pay`s the most taxes (Wikipedia, 2020). Two models that analyzed the benefit approach are: the Lindahl and Bowen models.

\section{The Ability to Pay Theory}

According to this theory, taxes should be founded upon the earnings of people and the amount they can pay without quid pro quo. For example, those who earn more money are expected to pay a higher rate of tax, compared to the low income earners (Wikipedia, 2020).

The ability to pay theory implies that individuals with higher income should bare the tax burden. That is, money for public expenses should be gotten from "him with surplus" not "him with deficit". In other words, individuals and companies should pay taxes based on their earnings (Omodero \& Amah , 2018). This doctrine has been in vogue for at least as long as the benefits theory. The taxes paid under this theory are perceived as sacrifice by taxpayers who increase the issue of what the sacrifice of each taxpayer should be and how it should be calculated.

\section{Empirical Review}

Nwaorgu, Oyekezie, and Abiahu (2020), who considered five years of data from ten listed manufacturing enterprises in Nigeria from 2013 to 2017. The Ex-post facto research design data was used in the study, and were analyzed using basic linear regression. The findings confirmed that the corporation tax rate has no substantial impact on firms' returns on equity.

Olaoye and Oluwatoyin (2019) explored determine the impact of corporate income tax on company profitability in Nigeria for the period 2007 to 2016. The estimate approach used in the study was pooled ordinary least squares, and the results revealed that corporation income tax has a positive coefficient and significant value of 2.418830, with P-values of 0.0000 .

Omodero and Amah (2018) conducted research on Corporate Tax and Deposit Money Bank Profitability in Nigeria. Because the data were secondary and already existed, the study used employed the use of causal research design. The data were acquired from public audited financial statements of twenty-one (21) Nigerian money deposit institutions. And employed the Multiple regression analysis and the student t-test were utilized as statistical techniques in the investigation, and the hypothesis was tested at a 5\% level of significance. Based on their results, they urge that the country's fiscal policy take into account the circumstances surrounding banks' activities in Nigeria, as well as the role they play in the nation's search for and pursuit of economic progress.

To assess the impact of corporate income tax on financial performance, Otwani, Namusonge, and Elizabeth (2017) used a mixed research design. Using Secondary data and also a sample size of 59 companies publicly listed on Kenya's Stock Exchange (KSE) were acquired. Firm Size and Liquidity, Investment, and Age/Debt were the independent variables, whereas profitability and Return on Investment of enterprises were the dependent variables. The findings of their study found that corporate income tax has a considerable positive impact on the financial performance of companies listed on Kenya's Nairobi Securities Exchange (NSE), and they supported regulations that ensure and guarantee that companies pay their corporation taxes on time.

Ileana et al. (2016) investigated the effect of corporate taxes on firm financial performance. The data for the study came from the firms' published audited financial statements for the three (3) years from 2012 to 2014. Their study used a total of twenty (20) enterprises registered on the Bucharest Stock Exchange as a sample size. The multi-regression analysis was used to analyze the data, and two representative indicators, net profit and economic profitability (return on assets), were chosen as dependent variables, while the independent variables were the effective tax rate, firm size, asset structure, long-term debt to total assets ratio, and financial leverage. Independent factors having no substantial impact were left out of the study. The study came to the conclusion that corporation taxes and the effective tax rate had a detrimental impact on firm financial performance. 
Chude and Chude (2015) used the Brewery Industry as a case study to investigate the influence of corporate income taxation on company profitability in Nigeria. All of the variables in the analysis were based on secondary data acquired from Brewery firms' published annual financial statements. The organization's earnings per share (EPS) was the dependent variable, whereas the business income tax was the explanatory variable (CIT). The effect of CIT on EPS was tested using the Augmented DickeyFuller (ADF) unit-root test at a 5\% level of significance. The findings revealed that there is a long-run equilibrium relationship and that CIT has a positive substantial impact on EPS (P-Value 0.0000.05). The study found that Company Income Tax (CIT) had a substantial impact on the profitability of Nigerian breweries, and it presented recommendations to improve tax management.

Ezugwu and Akubo (2014) conducted an empirical study on the impact of high corporation tax rates on firm profitability in Nigeria. The study's problem was the extent to which Nigeria's high corporation tax rate threatens the viability of businesses. The study employed a causal research methodology and a multi-regression statistical technique to analyze secondary data from the Federal Inland Revenue Service (FIRS), with a population of 45 corporate organizations in Lagos and a sample size of 41 participants. Corporate profitability (dependent) and corporate tax rates (independent) were the study variables, and the data was analyzed using the Statistical Package for Social Sciences (SPSS 17). The study discovered that the corporation tax rate and realized profit of enterprises have a favorable link. As a result, it was suggested that the Nigerian corporate tax rate, which is now set at $30 \%$ of assessable profit, be cut in order to avoid negative economic consequences in the country.

Oloidi (2014) investigated the impact of Company Income Tax (CIT) on investment decisions made by enterprises subject to the Nigerian Company Income Tax Act. A questionnaire was created and distributed to 180 businesses in the southwest zone. The findings demonstrated that corporate income tax has an impact on the rate of return on investment and the criteria used to evaluate investments; tax incentives encourage investment. When analyzing the factors that influence investment decisions in the country, taxation was perceived as playing a larger effect. The research did, however, make a proposal to the government to create a tax policy that would encourage economic growth and development and also encourage investment.

From 1980 to 2010, Edame and Okoi (2014) investigated the impact of taxation on investment and economic growth in Nigeria. Secondary data was gathered from the Nigerian Central Bank (CBN), statistical bulletins, and the National Bureau of Statistics (NBS). The results of the analysis revealed that the parameter estimates for Corporate Income Tax (CIT) and Personal Income Tax (PIT) are both negative, indicating an inverse relationship. The implications of the findings are that a one percent increase in the Corporate Income Tax (CIT) will result in a decrease in the level of investment in Nigeria, and a one percent increase in the Personal Income Tax (PIT) will result in a reduction in the level of investment, demonstrating that taxation is negatively related to investment.

The influence of corporation taxation on firm reserves and dividends in Nigeria was investigated by Onuorah and Chigbu (2013) using the Ordinary Least Square (OLS) technique. Secondary data from selected banking, construction and related companies, insurance, petroleum and marketing, breweries, food and beverage companies, and conglomerates was used in the study, which covered the period 20002011 and was obtained from a variety of sources, all of which are listed on the Nigeria Stock Exchange. Annual dividend payments were used as the dependent variable, with annual corporate tax expenses, earnings per share, and returns on earnings per share as the independent factors. According to the study's findings, corporate taxes have no impact on a company's reserve or dividend payment. As a result, the study recommends proper tax restructuring that will not affect regular dividend payments in order to encourage the public to invest and businesses to develop.

Gatsi, Gadzo, and Kportorgbi (2013) investigated the impact of corporate income tax on the financial performance of Ghana's publicly traded manufacturing enterprises. The study discovered a negative but substantial relationship between manufacturing enterprises' financial performance and corporate income tax in Ghana. 


\section{METHODOLOGY}

The study adopted causal research design since the data gathered on the selected variables were historical and already in existence thereby reducing the chances for data manipulation. All the data collected were secondary and was obtained from published audited financial statements of the selected companies listed on Nigerian Stock Exchange (NSE). The data covered the period from 2011 to 2020 (ten years). The population of this study comprised all listed companies on the Nigerian Stock Exchange (NSE) which stands at (161) as at April 2021. Due to the population size, the study adopted a stratified random sampling method based on the judgment of the researcher after considering the following; firstly, the companies must be incorporated before 2011. Secondly, all firms selected for the purpose of this study must have their audited financial statement for the period under consideration (2011-2020) and finally, the firms must not have been delisted by NSE between the periods under consideration. The total sample drawn is was fifteen companies.

Two of the three economic models were adopted and the third modified for the purpose of this research and are specified as follows:

$$
\mathrm{PAT}=\dot{\alpha}+\beta 1(\mathrm{CIT})+\varepsilon
$$

As adopted from Omodero and Amah (2018) where PAT is Profit After Tax, $\dot{\alpha}$ is the intercept term, $\beta 1$ is the regression coefficient CIT is the Company income tax, $\varepsilon$ is the error term.

$\mathrm{EPS}=\grave{\alpha}+\beta 1(\mathrm{CIT})+\varepsilon$

As adopted from Chude and Chude (2015) where EPS is the earnings per share, $\dot{\alpha}$ is the intercept term, $\beta 1$ is the regression coefficient CIT is the Company income tax, $\varepsilon$ is the error term.

$\mathrm{ROE}=\dot{\alpha}+\beta 1(\mathrm{CIT})+\beta 2(\mathrm{CSHF})+\varepsilon$

As modified from Kurawa and Saidu (2018) where ROE is the returns on equity, $\dot{\alpha}$ is the intercept term, $\beta 1$ is the regression coefficient of CIT, CIT is the Company Income Tax; $\beta 2$ is the regression coefficient of CSHF, CSHF is change in shareholders fund, $\varepsilon$ is the error term.

\section{Descriptive Statistics}

\section{DATA ANALYSIS AND PRESENTATION}

The summary statistics of the explained and the explanatory variables are presented in Table 1 where minimum, maximum, mean, standard deviation, and skewness of the data for the variables in the study are described.

Table 1. Descriptive Statistics

\begin{tabular}{|l|l|l|l|l|l|}
\hline & PAT & ROE & EPS & CIT & CSHF \\
\hline Mean & 14415307.09 & 0.24132204 & 13.22508333 & 5832316.72 & 9049029.883 \\
\hline Standard Error & 1855322.653 & 0.020076144 & 2.542546973 & 697119.4739 & 2166330.895 \\
\hline Median & 7477704 & 0.190190995 & 3.77 & 3042050.25 & 2523087.5 \\
\hline $\begin{array}{l}\text { Standard } \\
\text { Deviation }\end{array}$ & 20324041.37 & 0.219923136 & 27.85220662 & 7636561.222 & 23730965.96 \\
\hline Sample Variance & $4.13067 \mathrm{E}+14$ & 0.048366186 & 775.7454134 & $5.83171 \mathrm{E}+13$ & $5.63159 \mathrm{E}+14$ \\
\hline Kurtosis & 6.70788082 & 2.789054818 & 23.67067161 & 4.131825957 & 12.94341918 \\
\hline Skewness & 2.375764647 & 1.532932919 & 4.306784558 & 1.970328623 & 3.280868387 \\
\hline Minimum & -17073641 & - & -16 & -5122092.3 & -20683282 \\
\hline & & 0.210657474 & & & \\
\hline
\end{tabular}




\begin{tabular}{|l|l|l|l|l|l|}
\hline Maximum & 106009690 & 1.047684916 & 211 & 37776636.9 & 144301406 \\
\hline Sum & 1729836851 & 28.95864474 & 1587.01 & 699878006.4 & 1085883586 \\
\hline Count & 120 & 120 & 120 & 120 & 120 \\
\hline
\end{tabular}

Source: SPSS 2020

Table 1 shows the detail account of the descriptive statistics for the explained and explanatory variables respectively. The table shows a mean of 14415307.09 for profit after tax (PAT) with the minimum and maximum of -17073641 and 106009690 respectively and a standard deviation of 20324041.37. This shows that on the average, companies earned $\$ 14415307.09$ as profit after tax with a maximum loss of $\$ 17073641$ and a maximum profit of $\$ 106009690$. The standard deviation of 20324041.37 implies that profit after tax of the companies under study deviated from its mean value up to 20324041.37. Similarly, the study records a mean of 0.24132204 for returns on equity (ROE) meaning that the average returns on equity of the companies for the period under study is 0.24132204 with a minimum and a maximum -0.210657474 and 1.047684916 respectively and a standard deviation of 0.219923136 which suggest a considerable level of dispersion within the period under study. Earnings per share (EPS) also have a mean of $\$ 13.22508333$ with a minimum and a maximum of $\$ 16$ and $\$ 211$ respectively. The standard deviation of $\$ 27.85220662$ suggests that earnings per share through the analysis deviate from its mean value up to a considerable level of $\$ 27.85220662$ during the period under review. Company income tax (CIT) as measured from the financial statement has a mean of 5832316.72 with the minimum and maximum of -5122092.3 and 37776636.9 respectively and a standard deviation of 7636561.222. This shows that on the average, companies paid $\$ 5832316.72$ as profit after tax with a maximum loss of $\$-5122092.3$ and a maximum profit of $\$ 37776636.9$. The standard deviation of 7636561.222 implies that profit after tax of the companies under study deviated from its mean value up to 7636561.222. Also the Change in shareholder's funds (CSHF) has a mean of 9049029.883, with a minimum and maximum number of -20683282 and 144301406 respectively. Skewness measures the degree of asymmetry of the distribution of the series around its mean (Spiegel \& Larry, 2011). Furthermore, the skewness of any given normal distribution is zero. A distribution is positively skewed if that distribution has a long right tail and negatively skewed if that distribution has a long left tail. From the above table we observe that PAT, ROE, EPS, CIT and CSHF all have positive skewness and as such they have long right tails. Similarly, kurtosis measures the extent to which a given distribution is peaked or flat i.e. the peakedness or flatness of the distribution, usually taken relative to a normal distribution (Spiegel \& Larry, 2011). If the kurtosis is above three, then the distribution is peaked or leptokurtic relative to the normal and if the kurtosis is less than three, the distribution is flat or platykurtic relative to normal distribution. From table above, it is observed that PAT, EPS, CIT and CSHF are all above three therefore this suggests that these variables are leptokurtic while ROE is platykurtic.

\section{Correlation Analysis}

Table 2. Below shows the extent of correlation coefficients of the relationship between the dependent variables (PAT, EPS, and ROE) and explanatory variable (CIT, and CSHF).

Table 2. Correlation analysis

\begin{tabular}{|l|l|l|l|l|l|l|l|}
\hline & $P A T$ & $R O E$ & EPS & CIT & CSHF & LOG(EPS) & $\begin{array}{l}\text { LOG } \\
(C I T)\end{array}$ \\
\hline PAT & 1 & & & & & & \\
\hline ROE & 0.296443799 & 1 & & & & & \\
\hline EPS & -0.036091468 & 0.261549 & 1 & & & & \\
\hline CIT & 0.988367985 & 0.333942 & -0.032 & 1 & & & \\
\hline CSHF & 0.665462028 & -0.01867 & -0.09622 & 0.64638 & 1 & & \\
\hline
\end{tabular}




\begin{tabular}{|l|l|l|l|l|l|l|l|}
\hline $\begin{array}{l}\text { LOG } \\
(\mathrm{EPS})\end{array}$ & 0.054599694 & 0.472163 & 0.756482 & 0.063963 & -0.07992 & 1 & \\
\hline $\begin{array}{l}\text { LOG } \\
(\mathrm{CIT})\end{array}$ & 0.503833933 & 0.455984 & 0.099784 & 0.519126 & 0.320938 & 0.242736632 & 1 \\
\hline
\end{tabular}

Source: SPSS 2020

The values of any correlation coefficient should range from -1 to 1 indicating the direction of the relationship (positive or negative), with larger values representing stronger relationships. The result reveals that all the explanatory variables are positively correlated (move in the same direction) except CSHF, CIT which are negatively correlated with ROE and EPS respectively. The figures reveal that company income tax (CIT) is more correlated with profit after tax (PAT) as it gives a correlation figure of 0.988367985 , followed by the LOG (EPS) which has the least correlated figure of 0.242736632 .

\section{Discussion of Findings}

From the foregoing analysis, it was observed that CIT has a positive and significant effect on profit after $\operatorname{tax}$ (PAT) in Nigeria that is if there is a unit increase in Company income tax (CIT), profit after tax (PAT) will increase with 2.630455. This finding is in line with that of Olaoye and Oluwatoyin (2019) who carried out a study to ascertain the effect of company income tax on the profitability of companies in Nigeria from 2007-2016 using regression analysis. Their study revealed that there is a positive and significant relationship between company income tax and profit after tax of the firm. The result was also consistent with Ezugwu and Akubo (2014) who also carried-out a study on the effect of high corporate tax rate on the profitability of corporate organizations in Nigeria. With an observation of forty-one firms using the regression analysis, their study revealed that there is a positive relationship between corporate tax rate and realized profit.

It was also observed that CIT has a positive and significant effect on ROE while CSHF have a negative but yet significant effect on ROE. The result obtained is in line with that of Otwani, Simiyu, and Makokha, (2017) that carried out a study to ascertain effect of corporate income tax on financial performance of companies listed on the Nairobi securities exchange in Kenya. The results established that corporate income tax was found to significantly and positively influence financial performance of companies listed on the NSE in Kenya to a very high extend. In addition, the findings indicate that the ratios of firm's profitability have the most significance in determining the financial performance of companies listed on the NSE in Kenya. The result was however not consistent with the findings of (Gatsi, Gadzo, \& Kportorgbi, 2013) which revealed a negative but significant relation between financial performance and corporate income tax of manufacturing firms in Ghana.

Lastly, it was observed that LOGCIT has a positive and significant effect on LOGEPS. The result obtained is in line with that of Chude and Chude (2015) that carried out a study on the Nigerian breweries using thirteen (13) observations on the impact of company income taxation on the profitability of companies in Nigeria. The results established that company income tax (CIT) has significant effect on the profitability of Nigeria breweries (EPS). However the findings was inconsistent with Nwaorgu, Oyekezie, and Abiahu (2020) who examined a five years data spanning from 2013-2017 of ten listed manufacturing firms in Nigeria revealed that there is no significant effect of corporate tax rate on returns on equity of the firms.

\section{CONCLUSION AND RECOMMENDATIONS}

The importance of taxation on the revenue generated by the federation cannot be overemphasized however the tax environment needs to be made better by both the government and its agencies. Effective tax administration designed to enhance revenue generation should also take into consideration the effect it would have on firms finance. Taxation, an instrument of fiscal policy is supposed to regulate, control and manage the economy in all ramification should be neutral and unbiased in its dealings so as to encourage companies to retain some of their profit, to invest, diversify and create employment opportunities in the country. 
From the result of this study, it is concluded that company income tax significantly affect the profit after tax, performance of the firms and earnings of shareholders. This implies that as corporate performance increases, so also does the company income tax levied against the company, thereby cutting down on the company's ability to retain profit which could be channeled into other productive activities. From the analysis carried out the study recommends the following:

- The fiscal policy adopted in Nigeria should consider the circumstances surrounding the activities of companies located in the Country and the special role they play in the pursuit of economic growth of the nation.

- Tax incentives and positive tax reforms that could reduce the burden and liability of tax on companies in Nigeria should be incorporated in the fiscal policy to encourage their business activities and going concern.

- New regulations to curtail excess corporate tax rather than eliminate corporate tax is necessary to enable companies have enough liquidity to meet its short term liabilities as they fall due should be adopted. A reduction in the corporation tax rate will therefore cause a decrease in the reasons to shift profits out and will indirectly upsurge the level of investment flowing into the country.

- The government should ensure that revenue generated from corporate tax especially company income tax (CIT) should be utilize in the development of the general economy so as to improve the standard of living of her citizenry and increase its Gross Domestic Product (GDP).

\section{AUTHOR CONTRIBUTIONS}

Conceptualization: Akadakpo Bukola Adefunke, Akogo Obehi

Data Curation: Akadakpo Bukola Adefunke, Akogo Obehi

Formal Analysis: Akadakpo Bukola Adefunke, Akogo Obehi

Funding Acquisition: Akadakpo Bukola Adefunke, Akogo Obehi

Investigation: Akadakpo Bukola Adefunke, Akogo Obehi

Methodology: Akadakpo Bukola Adefunke, Akogo Obehi

Project Administration: Akadakpo Bukola Adefunke, Akogo Obehi

Resources: Akadakpo Bukola Adefunke, Akogo Obehi

Software: Akadakpo Bukola Adefunke, Akogo Obehi

Supervision: Akadakpo Bukola Adefunke, Akogo Obehi

Validation: Akadakpo Bukola Adefunke, Akogo Obehi

Visualization: Akadakpo Bukola Adefunke, Akogo Obehi

Writing - Original Draft: Akadakpo Bukola Adefunke, Akogo Obehi

Writing - Review \& Editing: Akadakpo Bukola Adefunke, Akogo Obehi

\section{CONFLICT OF INTEREST STATEMENT}

The authors declare that they have no competing interests.

\section{ACKNOWLEDGEMENT}

All authors contributed equally to the conception and design of the study.

\section{REFERENCES}

Adejare, A. T. (2015). The analysis of the effect of corporate income tax (CIT) on revenue profile in nigeria. American Journal of Economics, Finance and Management, 1(4), 312-319.

Agbetunde, A. L. (2010). Principles and practice of Nigeran personal income tax. Lagos: Feetal Consulting.

Chude, I. D., \& Chude, N. P. (2015). Impact of company income taxation on the profitability of companies in Nigeria: A case study of Nigerian breweries. European Journal of Accounting, Auditing and Finance Research, 3(8), 1-11. 
Cordelia, O. O., \& Amah, K. O. (2018). Corporate Tax and Profitability of Deposit Money Banks in Nigeria. Journal of Accounting, Business and Finance Research, 47-55.

Edame, G. E., \& Okoi, W. W. (2014, july). The impact of taxation on investment and economic development in Nigeria. Academic Journal of Interdisciplinary Studies, 3(4), 204.

Ezugwu, C.I, \& Akubo, D. (2014). Analysis of the effect of high corporate tax rate on the profitability of corporate organisations in nigeria - A study of some selected corporate organisations. Mediterranean Journal of Social Sciences, 5(20), 310.

Federal Inland Revenue Service. (2020). Tax Statistics/Reports. Retrieved from https://www.firs.gov.ng/TaxStatisticsReports

Gatsi, J. G., Gadzo, S. G., \& Kportorgbi, H. K. (2013). The effect of corporate income tax on financial performance of listed manufacturing firms in Ghana. Research Journal of Finance and Accounting, 4(15), 118-124.

Ileana, P. C., Aurelia, S., Minzu, V. G., Popa, A. F., \& Niculescu, A. M. (2016). Research of Corporate Tax Impact on Financial Performance. Case of Companies Listed on Bucharest Stock Exchange. Management and Economics Review, 1(2), 203-216.

Institute of Chartered Accountants of Nigeria. (2019). Advance Taxation. Lagos: Institute of Chartered Accountants of Nigeria (ICAN).

KPMG Nigeria. (2019). Nigeria Tax Journal, 1-53.

Kurawa, J. M., \& Saidu, H. (2018). Corporate tax and financial performance of listed Nigerian consumer goods. Journal of Accounting and Financial Management, IIARD-International Institute of Academic Research and Development, 4(4), 30-43.

Nwaorgu, I. A., \& Abiahu, M. F. C. (2020). Effect of Corporate Tax on Sustainable Financial Performance of Listed Firms in Nigeria. Abiahu, MC \& Nwaorgu, IA (2020). Effect of Corporate Tax on Sustainable Financial Performance of Listed Firms in Nigeria. Journal of Taxation and Economic Development, 19(1), 50-63.

Olaoye, O. C., \& Oluwatoyin, A. E. (2019). Effect of corporate taxation on the profitability of firms in Nigeria. Journal of Economics and Behavioral Studies, 11(1), 191-201.

Oloidi, G. (2014). Company Income Tax and InvestmentDecisions: A Behavioural Approach. Journal of Business and Management, 16(7), 11-19.

Omodero, C. O., \& Amah , O. K. (2018). Corporate Tax and Profitability of Deposit Money Banks in Nigeria. Journal of Accounting, Business and Finance Research, 3(2), 47-55.

Onuorah, A. C., \& Chigbu, E. E. (2013). A comparative analysis of the impact of corporate taxation on company's reserve and dividend policy in Nigeria: 2000-2011. Journal of Developing Country Studies, 3(1), 154-161.

Otwani, M. N., Namusonge, G. S., \& Elizabeth, N. M. (2017). Effect of corporate income tax on financial performance of companies listed on the Nairobi securities exchange in Kenya. International Journal of Social Sciences and Information Technology, 3(8), 2467-2477. 
Pricewaterhousecoopers. (2021, January 28). Corporate - Taxes on corporate income. Retrieved from https://taxsummaries.pwc.com/nigeria/corporate/taxes-on-corporate-income

Ra'Ed, M., Idries, J., \& Mohammad, T. (2015). Accounting vs Market Based Measures of Firm Performance related to Information Technology Investments. International Review of Social Sciences and Humanities, 9(1), 129-145.

Spiegel, M. R., \& Larry, S. J. (2011). Schaum's Outlines (Fouth ed.). United State of America: McGrawHill companies, inc.

Wikipedia. (2020). Nst income. Retrieved from https://en.wikipedia.org/wiki/Net_income

Wikipedia. (2020, December 21). Theories of taxation. Retrieved from https://en.wikipedia.org/wiki/Theories_of_taxation

Wigmore, I. (2015). Corporate performance. Retrieved from https://whatis.techtarget.com/definition/corporateperformance\#: : :text=Corporate $\% 20$ performance $\% 20$ is $\% 20 \mathrm{a} \% 20$ composite,financial $\% 2 \mathrm{C} \% 20$ market\%20and\%20shareholder\%20performance.

\section{Copyrights}

Copyright for this article is retained by the author(s), with first publication rights granted to the journal. This is an open-access article distributed under the terms and conditions of the Creative Commons Attribution license (https://creativecommons.org/licenses/by/4.0). 